\title{
Financial Leverage and Service Sector Firms
}

\author{
Hassan Fayyaz Chaudhry
}

\begin{abstract}
The study was done to probe the determinants of financial leverage of non-financial firms of service sector, listed on Karachi Stock Exchange, Pakistan for the period of 10 years form 2003-13. The sample of 57 companies was taken from listed non-financial firms on KSE. The sample was equally distributed and well organized to cover all service sectors of population. The regression model was applied on data while taking financial leverage as an independent variable. The study results and conclusions show that there exist a significant relationship.
\end{abstract}

Keywords: Financial leverage, KSE, Service Sector, Determinants

\section{Introduction}

The study examines the determinants of financial leverage of KSE listed non-financial service sector firms for the period of 10 years form 2003-13. The capital structure theory gives an idea that how firms finances its assets through equity and debts. It suggest industrialists to utilize the equity and debts to generate earnings and finance their business. So the financial leverage is the combination of equity and debts, which is defined as capital structure of the firm. Capital structure theory and its pioneers Modigliani and Miller(1958,1963) were of viewed that the value of business is different from mode of financing either equity or debt. They assumed that taxes play a prominent role in capital structure of the firm. Similarly Watson (1983) analyzed that weighted average cost of capital (WAC) remains unchanged with change in financial leverage status of the firm. So firms those are having higher and boosted level of leverage are in a position to decrease down their cash flow level. Similarly when capital structure of firm reaches at high level of debt equity ratio then risk of bankruptcy also increases. Free cash flows determine that company has an ability to generate a pool of money in order to save its assets. Similarly free cash flows make the company on track of investment and try to protect and raise the income of shareholders and also their wealth level. Literature on capital structure reveals that three main models of finance; Free cash flow theory, trade off theory and pecking order theory are responsible for majority of capital decisions made by firms.

The trade off theory is of viewed that firms have advantage to finance through debts; in the form of tax benefits and other hand have cost of financing through debts ; in the form of bankruptcy cost and financial distress (Butters, R . 1949). So results of trade off theory suggests that firm should maintain an optimize and balance level between equity and debt financing while taking in view of benefits of taxes and costs of financial distress (Myers 1984).

The decisions of financing through equity or debts depends upon the future expectations of the firm; if firm is expecting an inflow or outflow of cash in future then their financing will change to either debt or equity. The theory reveals that some time firms try to utilize both options of equity financing and debt financing in a specific ratio so that benefits of taxes are maximized and cost of financial distress and bankruptcy is minimized. Prior studies on trade off theory; view that firms preferred to finance through external funding; in the form of debts rather than equity or internal financing (Myers 1984). Trade off theory categorized the financing sources in to three main divisions; first one is the internal financing, $2^{\text {nd }}$ one is debt and third option is external equity financing. In above all three sources, the least expensive is first one and highly expensive is external equity financing. So firms will prefer to utilize least expensive source or mixture of two sources. In 1958, 
Miller and Modigliani predicts that the information regarding firms decisions and their financial conditions is mostly available to management; which is inside the organization and on the other hand the investor; who is outside the organization is not aware of happenings inside the organization. So Meckling, 1976 reveals that a dispute may occur between investors and management which will lead to generate another cost; known as agency cost. However, if the firms management has selected least costly financing or a suitable financing source then agency cost may decrease but on the other hand wrong decision will lead to dispute among investor and management. So literature of prior studies reveal that management due to having inside information have information advantage on the hand investor has to rely on management decisions and their results (Myers \& Majluf, 1984).

\section{Determinants Of Financial Leverage}

Financial leverage word relates to the gearing up the firm with financing sources. Similar to functioning of lever in mechanics to lift up the weight, using machine like lever, financial leverage is the financing to increase profitability.

\section{Financial leverage $\quad=\quad$ Total liabilities / Equity}

The risk of default to pay their debts and bankruptcy are linked with high level of borrowing during recession in business era while on the other hand firms having less number of borrowing will be able to pay off their debts easily and their risk of bankruptcy is very minute or even zero. This research focuses on determining the impact of these variables; which are chosen from prior studies literature. The variables include; Firm Growth, Size of firm, Profitability, tangibility and liquidity.

\section{Firm's Growth}

Firms growth is measured as a constructive change or increase in the firm's size on a specific period of time. It is mainly annual growth in firms total assets from previous year. The higher growth rate is the indicator that firm is financially strong enough to raise more funds through external sources of financing but on the same time firm with higher growth rate needed huge amount of finance for its support and backup. Growth is an intangible asset and it is very difficult to collateralize it. Prior studies found positive(Rajan, R. 1995) and some found negative relation of firm growth rate and financial leverage (Zhao Bei, 2012).

\section{FIRM'S SIZE}

Firm size is the measured of natural log of total assets. According to trade off theory firms basing on costs and benefits of decisions decide the level of debt and equity financing. The firms with high growth rate and huge capital and asset structure are more diversified to lower the risks of default and bankruptcy (Qureshi, M.A ,2009). Similarly the prior studies reveal that the larger firms decrease their transaction cost by issuing long term debts with low rates of interest.(Argawal, A. et al 1990). So firm size has positive relationship with financial leverage.

\section{FIRM'S PROFITABILITY}

Profitability of firm is the firm is calculated as the returns on total assets. The view of pecking order theory; firms try to reduce or minimize their external high cost sources of financing and prefer less costly internal sources, so the bankruptcy risk is reduced. Prior studies reveal that all those firms which are having high profitability level are less risky and they can issue debts at very low rate of interest (Akhtar, S. et al 2009; Baskin, J. 1989). 


\section{FIRM'S LIQUIDITY}

Liquidity of the firm is measured as the ratio of current assets to current liabilities. Liquidity is the amount of cash which is available to firm to invest. Prior studies reveal that liquidity of the firm is to meet their current liabilities. So on having huge amount of cash will help the firm to reduce its liabilities and decrease the risk of default (Allen, D.E, 1993; Al-Najar, B. 2011). The firms having huge amount of current assets would have source of internal funding. Similar to above views literature show same results (Buferna, F. et al 2005; Butters, K. 1949).

\section{FIRM'S TANGIBILITY}

Tangibility is the measured of ratio between fixed assets to total assets. One of the most important and fundamental determinant of financial leverage. Prior studies conclude that firms with less number of tangible assets would have low financial leverage ratio so it become difficult to collateralize those assets, hence it become difficult for firm to raise funds which will definitely lead to increase the risk of bankruptcy and default, a positive relationship is expected similar to previous studies (Titman, S. et al 1988; Rajan, D. et al 1995; Qureshi, M. et al 2012).

\section{Methodology}

The data was collected from annual reports of 54 listed non-financial service Karachi Stock Exchange for the period of 10 years from 2003-13. Model is adopted from the study of liaqat Ali, 2011.

Financial leverage $=\mathbf{a}+\alpha_{1}$ Growth $+\alpha_{2}$ Size $+\alpha_{3}$ Profitability $+\alpha_{4}$ Liquidity $+\alpha_{1}$ Tangibility

\section{Empirical Results}

The data of sample was analyzed using regression model and an insignificant relationship was found between financial leverage and other studied variables in this study.

\section{Coefficient Correlations}

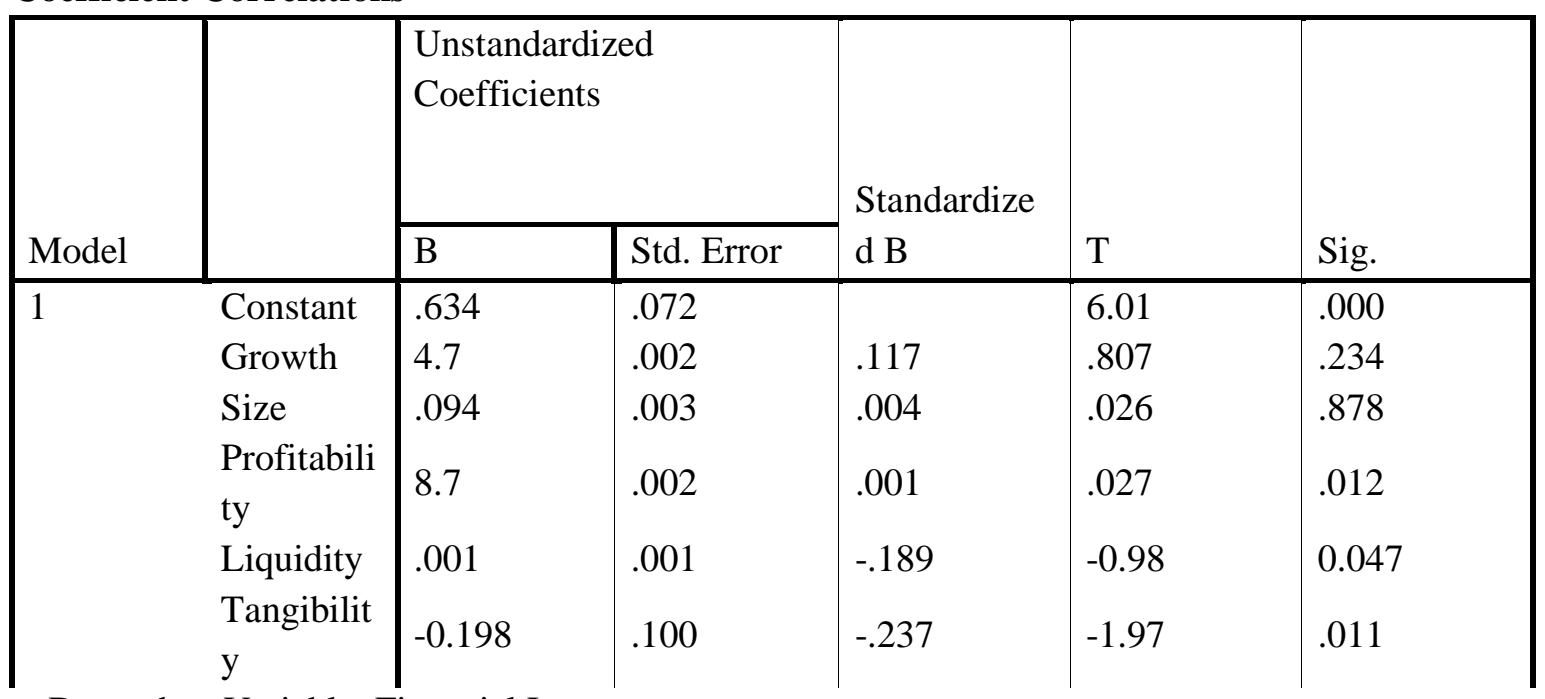

a Dependent Variable: Financial Leverage

The results are very impressive and we found a consistency of our study results with prior studies of (Titman, S. et al 1988; Rajan, D. et al 1995; Qureshi, M. et al 2012; Ross, S. 1977). The table shows that Growth rate has no significant relationship with financial leverage which is inconsistent with prior studies (Akhtar, S. et al 2009). Similarly firm size, tangibility, liquidity has shown insignificant relationship with financial leverage. These results are inconsistent with previous studies. 


\section{Conclusion And Recommendations}

This study was made on non-financial firms selected from population of KSE listed companies to explain the factors involved in determining the leverage. The results of the study are in consistent with previous studies and reveals that firms size matters a lot in determining its leverage. The study was limited to non-financial service sector, future researcher can conduct study on both financial and non-financial manufacturing sectors also and can compare it with each other. The study will help financial analysts to incur financial positions of the firms.

\section{Refrences}

[1]. Agarwal, A., \& Nagarajan,J (1990). Corporate Capital Structure: The case of equity firms: The journal of Finance, 2(4), 36-87.

[2]. Akhtar,S., \& Oliver,B. (2009). Determinants of capital structure. International review of finance, 3(4), $234-296$.

[3]. Allen, D.E. (1993). The pecking order hypothesis. Applied financial Economics, 3(2), 112-139.

[4]. Al-Najjar, B. (2011). The interrelationship between capital Structure and dividend policy. International Review of Applied Economics, 23(3),311-324

[5]. Bufema, F.M. (2005). Determinants of capital structure. (Vol. 8) University of Liverpool.

[6]. Butters, J.K. (1949). Federal Income taxation and External vs Internal Financing. The Journal of finance, 3(34), 173-195.

[7]. Jensen, M. \& Meckling, W. (1976). Managerial behavior, agency costs and ownership structure. Journal of financial economics, 2(4), 205-260.

[8]. Ali, L. (2011). The determinants of Leverage. European Journal of Business and Management, 2(22), 47-56.

[9]. Modigliani, F. \& Miller, M. (1984). The cost of capital, corporate finance and the theory of investment. The American economic review, 47(3), 271-287.

[10]. Myers, S. \& Majluf, N. (1984). Corporate financing and investment decisions when firms have information that investors donot have. Journal of financial economics, 12(2), 143-201.

[11]. Qureshi, M. (2009). Does pecking order theory explain leverage bahaviour?. Applied Financial Economics, 18(16), 1265-1330.

[12]. Rajan, R. , \& Zingales, L. (1995). What do we know about capital structure?. The Journal of Finance, 48(4), 1432-1458.

[13]. Zhao, B. \& Wije, W. (2012). Financial Leverage, Firm growth and financial strength. Journal of Asia Pacific Business Innovation \& Technology Management, 3(2), 234 